\title{
Optimasi Hasil Akuisisi Wajah Dengan Variasi Proyeksi Menggunakan Kedekatan Pola Jarak Pixel
}

\author{
Yusi Aribah ${ }^{1}$, Arief Bramanto Wicaksono Putra ${ }^{2}$ \\ ${ }^{1,2}$ Jurusan Teknologi Informasi Negeri Samarinda, J1. DR. Ciptomangunkusumo, Kampus Gunung Lipan, Samarinda, Indonesia \\ correspondence email : ariefbram@polnes.ac.id
}

\begin{abstract}
Abstrak-- Akuisisi merupakan proses awal untuk mendapatkan citra digital. Pada penelitian ini menerapkan akuisisi dengan jenis-jenis proyeksi sudut yang bertujuan untuk menganalisis perbandingan hasil akuisisi yang data sudutnya bervariasi dari sebuah obyek wajah. Ekstraksi ciri dilakukan untuk memperoleh nilai spesifik dari akuisisi wajah, obyek penelitian berupa wajah memiliki 9 sampel dengan identitas sudut $0^{\circ},+15^{\circ},+45^{\circ},+75^{\circ},+90^{\circ},-15^{\circ},-45^{\circ},-75^{\circ}$, dan $-90^{\circ}$. Pada proses ekstraksi ciri menggunakan Correlation Coefficient semua hasil akuisisi obyek wajah telah melalui tahapan pre-processing. Pengujian performansi dari variasi proyeksi tersebut menggunakan metode Euclidean Distance sebagai pengukur jarak kedekatan antar variasi sudut, dimana selisih antar jarak yang diperoleh akan menjadi nilai dari performansi yang diinginkan. Hasil performansi akuisisi terbaik dari obyek $A$ adalah sudut $0^{\circ}$ terhadap $+15^{\circ}$ dan $-15^{\circ}$, obyek B sudut $0^{\circ}$ terhadap $+15^{\circ}$ dan $-15^{\circ}$, dan obyek $C$ sudut $0^{\circ}$ terhadap $+90^{\circ}$ dan $-90^{\circ}$.
\end{abstract}

Kata Kunci-Pengajaran; Akuisisi, Variasi; Sudut proyeksi

\section{PENDAHULUAN}

Akuisisi citra merupakan proses awal untuk mendapatkan citra. Tujuannya adalah untuk mendapatkan data yang diperlukan dan memilih metode perekaman citra. Proses ini dimulai dari persiapan obyek yang akan diambil gambarnya, alat-alat, dan proses pencitraannya. Pencitraan merupakan kegiatan transformasi dari citra tampak (misal: foto, gambar, lukisan) menjadi citra digital. [1][2][3]. Faktor yang menentukan keberhasilan proses akuisisi salah satunya adalah proyeksi. Proyeksi adalah ilmu yang mempelajari tentang cara menggambarkan penglihatan mata kita dari suatu benda tiga dimensi kedalam kertas gambar serta dua dimensi sehingga apa yang dilihat atau dipandang sesuai dengan penglihatan mata. Proyeksi menyatakan bentuk yang diperoleh dari hasil proyeksi objek terhadap garis sumbu. [4]

Berdasarkan acuan penelitian telah dilakukan pembuatan modul perangkat lunak akuisisi citra dan kendali meja putar yang digunakan untuk mengoperasikan perangkat penangkap citra radioskopi untuk industri manufaktur. Perangkat lunak ini mempunyai beberapa keunggulan antara lain yaitu tersedianya fitur integration frame yang digunakan untuk mengurangi noise dalam proses akuisisi citra. Selain itu, tersedia fitur temporal median fiter yang berguna untuk memperhalus kontur citra pada salah satu sisi citra. Perangkat lunak ini memiliki fitur kendali meja putar yang mampu melakukan akuisisi citra secara otomatis dengan proyeksi dari berbagai sudut. Hasil akuisisi citra tersebut disimpan secara otomatis dan kemudian digunakan untuk rekonstruksi tomografi. [3]. Berdasarkan acuan penelitian yang berkaitan dengan akuisisi menyatakan bahwa unjuk kerja model penentuan nilai standar distorsi pada akuisisi citra sidik jari sangat dipengaruhi oleh jumlah data training dan data testing serta nilai threshold yang digunakan. Semakin banyak data training yang digunakan, maka unjuk kerja system semakin baik. Demikian pula penggunaan nilai threshold. Nilai standar distorsi berminyak pada akuisisi citra sidik jari berdasarkan skor kejelasan dan rasio ketebalan ridge-valley yakni memiliki skor kejelasan lokal (LCS) sebesar 0,01446-0,01550, skor kejelasan global (GCS) sebesar 0,01186-0,01230, dan nilai rasio ketebalan ridge-valley (RVTR) sebesar 6,980E-05-7,22E-05. [5]

Berdasarkan acuan penelitian yang berkaitan dengan proyeksi menyatakan bahwa Semakin banyak data proyeksi yang digunakan maka kualitas citra CT yang dihasilkan semakin bagus. Dalam radioterapi, data proyeksi yang digunakan untuk merekonstruksi citra pada saat diagnosis dan selama terapi diambil pada posisi sudut yang sama, dengan jumlah sudut biasanya $<10$ sudut. Optimasi sudut-sudut proyeksi dengan metode optimasi gradient descent pada rekonstruksi citra CT dengan ART. Telah diperoleh bahwa dengan jumlah data proyeksi terbatas dan jumlah iterasi yang kecil dihasilkan kualitas citra CT yang bagus. Dengan demikian metode optimasi gradient descent merupakan metode optimasi yang efektif untuk 
mengoptimasi sudut pencitraan dalam merekonstruksi citra dengan ART. [6]

Pola adalah suatu entitas yang samar yang dapat diberi nama seperti : citra sidik jari, tulisan tangan, sinyal suara, wajah, urutan DNA, dan lain-lain. Fitur adalah atribut dari pola yang mendeskripsikan ciriciri pola dalam berbagai entitas tergantung dari polanya. Umumnya, fitur dari suatu pola dijital adalah berupa lebar atau tinggi obyek, intensitas warna, dan lain-lain. Fitur juga dapat berupa sekumpulan pengukuran secara statistik dari pixels-pixels yang ada yang dapat didasarkan pada posisi pixels, warna pixels, jarak antar pixels, dan lain-lain. [7][8]

Berdasarkan acuan penelitian yang berkaitan dengan metode fungsi Euclidean Distance menyatakan Pengenalan wajah erat kaitannya dengan biometrik, dikarenakan penggunaan karakter - karakter unik manusia. Banyak metode yang digunakan dalam pengenalan wajah, salah satunya yaitu dengan menggunakan fungsi jarak metode Euclidean. Metode Euclidean membandingkan jarak minimum image pengujian (testing), dengan database image pelatihan (training). Untuk ekstraksi ciri image citra digunakan metode SPCA (Simple Principle Component Analysis) yang lazim digunakan untuk penajaman citra pada proses pengenalan / identifikasi. [9][10]. Berdasarkan uraian diatas penelitian ini menerapkan jenis-jenis proyeksi yang bertujuan untuk menganalisis perbandingan hasil akuisisi yang data sudutnya bervariasi dari sebuah objek wajah wanita menggunakan kerudung. Hasil akuisisi yang bervariasi akan diekstraksi cirinya menggunakan Coefficient Correlation. Kemudian dari kumpulan ciri Coefficient Correlation dianalisis pengukuran jarak kedekatan hasil akuisisi dengan variasi sudut menggunakan metode Euclidean Distance guna mendapatkan perbandingan hasil akuisisi dengan nilai selisih jarak sudut kanan dan kiri..

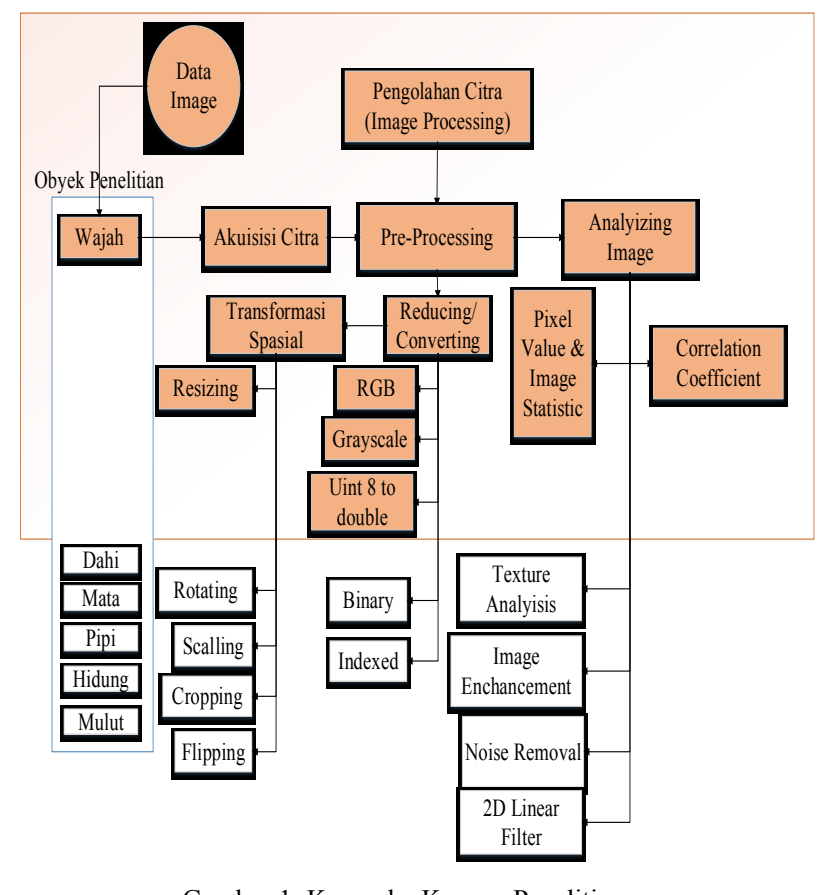

Gambar 1. Kerangka Konsep Penelitian

\section{METODE PENELITIAN}

\section{A. Metode Penelitian}

Gambar diagram alir atau metode penelitian yang disajikan dalam gambar 2. Tahap awal yang dilakukan terlebih dahulu adalah memilih obyek yang akan diakuisisi. Obyeknya diambil dari salah satu mahasiswa Politeknik Negeri Samarinda jurusan Teknologi Informasi. Kemudian dilakukan proses akuisisi citra dengan menggunakan kamera handphone untuk mendapatkan citra digital. Dalam penelitian ini, akuisisi dilakukan diruangan kelas gedung D4 jurusan Teknologi Informasi dengan kondisi ruangan tertutup dan pencahayaan lampu yang cukup ideal. Pada saat pengambilan akuisisi untuk mendapatkan sudut-sudut proyeksi kameranya yang bergerak pada dan jarak pengambilannya sangat dekat (close up).

Optimasi Hasil Akuisisi Wajah Dengan Variasi Proyeksi Menggunakan Kedekatan Pola Jarak Pixel (Arief Bramanto Wicaksono Putra) 


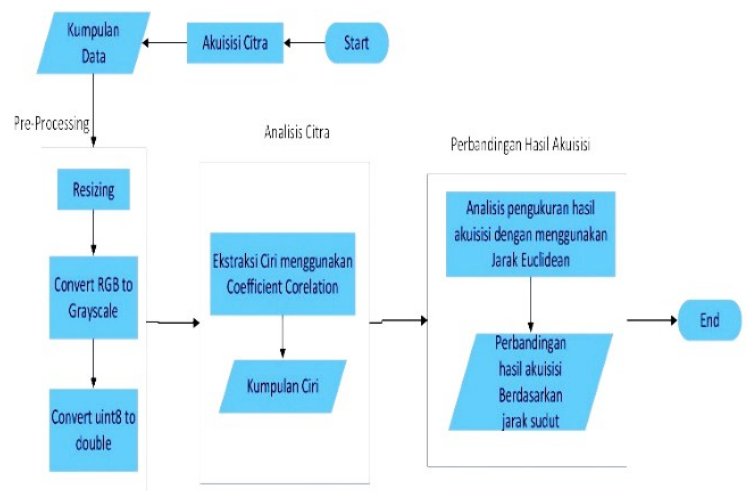

Gambar 2. Metode Penelitian

Setelah tahap akuisisi dilakukan maka hasil akuisisi yang didapatkan adalah pengumpulan data citra. Kemudian dilakukan tahap pre-processing menggunakan tools Matlab. Tahap pre-processing yang dilakukan meliputi resize image, pembacaan data image, konversi citra RGB menjadi Grayscale, dan konversi format citra uint to double.

Tahap selanjutnya adalah ekstraksi ciri. Metode yang digunakan dalam penelitian ini adalah ekstraksi ciri dengan coefficient correlation. Data yang didapatkan adalah kumpulan ciri dari setiap sudutnya. Setelah mendapatkan kumpulan cirinya setiap sudut proyeksi dilakukan pengukuran hasil akuisisi setiap citra dari sudutnya dengan menggunakan metode Euclidean Distance.

\section{B. Ekstraksi Ciri}

Ekstraksi ciri merupakan tahap yang harus dilakukan sebelum melakukan klasifikasi. Proses ini berkaitan dengan kuantisasi karakteristik citra ke dalam sekelompok nilai ciri yang sesuai. Ekstrasi ciri merupakan bagian fundamental dari analisis citra. Ciri adalah karakteristik unik dari suatu objek. Pada Penelitian kali ini metode ekstraksi yang digunakan adalah Coefficient corelation.

Ekstraksi ciri menggunakan correlation coefficient pada penelitian ini dengan menghitung nilai kesamaan dibandingkan ketidaksamaan, hasil dari perhitungan tersebut akan dirata- rata berdasarkan baris dan kolom untuk merepresentasikan ciri pada citra menggunakan correlation coefficient. [9][11]

Rumus dari correlation coefficient :

$$
s_{i j}=\frac{\sum_{k=1}^{n}\left(x_{i k}-\bar{x}_{l}\right) \cdot\left(x_{j k}-\overline{x_{j}}\right)}{\left[\sum_{k=1}^{n}\left(x_{i k}-\overline{x_{l}}\right)^{2} \cdot \sum_{k=1}^{n}\left(x_{j k}-\overline{x_{j}}\right)^{2}\right]^{\frac{1}{2}}}
$$

Keterangan :

Sij : Coefficient Corelation

$\mathrm{x}$ : Citra acuan (template)

$\mathrm{x}$ : Nilai rata-rata citra acuan

$y$ : Nilai rata-rata citra masukan

y : Citra masukan

$\mathrm{M}, \mathrm{N}$ : jumlah piksel citra

\section{Analisis Pengukuran Hasil Akuisisi}

Pengukuran hasil akuisisi untuk menentukan jarak sudut yang dilakukan menggunakan metode Euclidean Distance dengan membandingkan jarak minimum image pengujian (testing), dengan database image pelatihan (training). Euclidean Distance dari dua vektor $x$ dan $y$ dihitung dengan persamaan 3:

$$
d(x, y)=\left(\sum_{i}\left(x_{i}-y_{i}\right)^{2}\right) \frac{1}{2}
$$

Keterangan :

$$
\begin{array}{ll}
d(x, y) & =\text { Euclidean distance } \\
x_{i} & =\text { Citra Uji } \\
y_{i} & =\text { Citra Acuan }
\end{array}
$$

Optimasi Hasil Akuisisi Wajah Dengan Variasi Proyeksi Menggunakan Kedekatan Pola Jarak Pixel (Arief Bramanto Wicaksono Putra) 
Semakin kecil nilai $\mathrm{d}(\mathrm{x}, \mathrm{y})$, maka semakin mirip kedua vector dicocokkan/dibandingkan. Sebaliknya semakin besar nilai d(x,y) maka semakin berbeda kedua vektor yang dicocokkan. [6][12]

\section{HASIL DAN PEMBAHASAN}

Tahapan-tahapan yang telah dilakukan untuk memperoleh perbandingan hasil akuisisi berdasarkan sudut. Secara garis besar penelitian ini terdiri dari 5 (lima) tahapan umum, yaitu Akuisisi Citra, PreProcessing, Ekstraksi Ciri, Pengukuran Jarak Hasil Akuisisi, dan Pengujian yang akan dijelaskan sebagai berikut :

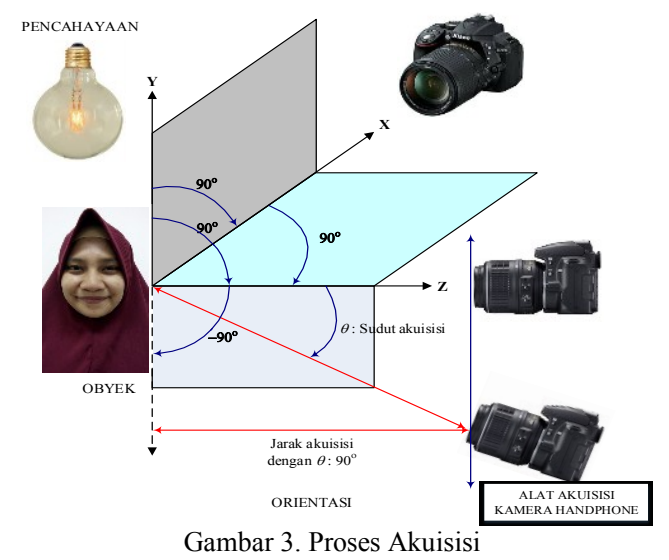

Berikut adalah gambar 4 yang menunjukkan contoh implementasi akuisisi data sudut $-45^{\circ}$ dari proses akuisisi yang dilakukan dipenelitian ini.

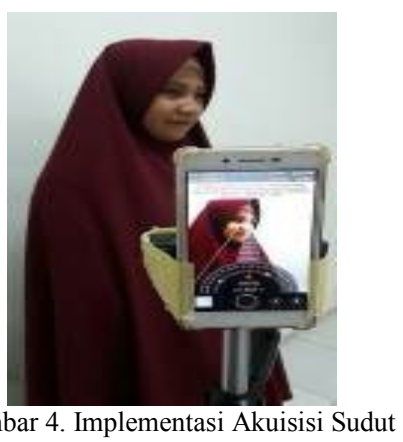

Pada gambar 5 adalah cara mengakuisisi nilai sudut $-45^{\circ}$ menggunakan aplikasi Compass S8. Setiap sudut yang digunakan juga diakuisisi dengan aplikasi tersebut.

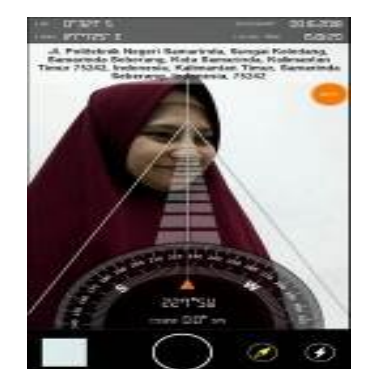

Gambar 5. Cara Akuisisi Sudut dengan aplikasi

Dengan sudut yang sama dan obyek yang berganti-gantian diakuisisi dengan aplikasi Compass S8 menghasilkan nilai sudut berdasarkan kompas tetapi system dari kompas tersebut telah bergerak dan kamera tersebut diam pada asumsi sudut yang ditentukan dengan busur. yang ditunjukkan pada tabel 1.

Table 1. Komparasi Sudut

\begin{tabular}{|l|l|l|l|}
\hline \multirow{2}{*}{ Asumsi Sudut } & \multicolumn{3}{|c|}{ Sudut dari Compass S8 } \\
\cline { 2 - 4 } & \multicolumn{1}{|c|}{ Min } & \multicolumn{1}{|c|}{ Max } & Rata-Rata \\
\hline Sudut $0 \circ$ & $179 \circ \mathrm{S}$ & $193 \circ \mathrm{S}$ & $186 \circ \mathrm{S}$ \\
\hline Sudut $+15^{\circ}$ & $157 \circ \mathrm{S}$ & $170 \circ \mathrm{S}$ & $163.5 \circ \mathrm{S}$ \\
\hline Sudut $+45^{\circ}$ & $133 \circ \mathrm{SE}$ & $148 \circ \mathrm{SE}$ & $140.5 \circ \mathrm{SE}$ \\
\hline Sudut $+75^{\circ}$ & $96 \circ \mathrm{E}$ & $112 \circ \mathrm{E}$ & $104 \circ \mathrm{SE}$ \\
\hline
\end{tabular}

Optimasi Hasil Akuisisi Wajah Dengan Variasi Proyeksi Menggunakan Kedekatan Pola Jarak Pixel (Arief Bramanto Wicaksono Putra) 


\begin{tabular}{|c|c|c|c|c|c|}
\hline & & \multirow{2}{*}{ Asumsi Sudut } & \multicolumn{3}{|c|}{ Sudut dari Compass S8 } \\
\hline & & & Min & Max & Rata-Rata \\
\hline & & Sudut $+90^{\circ}$ & $68 \circ \mathrm{E}$ & $85 \circ \mathrm{E}$ & $76.5 \circ \mathrm{E}$ \\
\hline & & Sudut $-15^{\circ}$ & $201 \circ \mathrm{SW}$ & $213^{\circ} \mathrm{SW}$ & $207 \circ \mathrm{SW}$ \\
\hline & & Sudut $-45^{\circ}$ & $225 \circ \mathrm{SW}$ & $241 \circ \mathrm{SW}$ & $233 \circ \mathrm{SW}$ \\
\hline & & Sudut $-75^{\circ}$ & $252 \circ W$ & $261 \circ W$ & $256.5^{\circ} \mathrm{W}$ \\
\hline & & Sudut $-90^{\circ}$ & $265^{\circ} \mathrm{W}$ & $275^{\circ} \mathrm{W}$ & $270 \circ \mathrm{W}$ \\
\hline Keterangan & $\begin{array}{l}+ \\
- \\
\text { S } \\
\text { SE } \\
\text { E } \\
\text { SW } \\
\text { W }\end{array}$ & $\begin{array}{l}=\text { Kanan } \\
=\text { Kiri } \\
=\text { Selatan } \\
=\text { Tenggara } \\
=\text { Timur } \\
=\text { Barat Daya } \\
=\text { Barat }\end{array}$ & & & \\
\hline
\end{tabular}

Dengan cara akuisisi sudut diatas mendapatkan hasil akuisisi obyek wajah dengan kamera handphone dan data citra yang didapat diambil 3 kali pengambilan setiap sudutnya. Pada penelitian ini meneliti hasil akuisisi berdasarkan sudut dari 3 obyek wajah. Dari setiap obyek hasil akuisisi yang didapatkan sebanyak 27 gambar yang nantinya akan diolah ke dalam proses pre-processing, kemudian dilakukan ekstraksi ciri dan pengukuran jarak hasil akuisisi dan diuji lagi dengan performansi hasil akuisisi performansi dengan nilai selisih antar jarak variasi sudut. Berikut adalah hasil dari akuisisi ditunjukkan pada gambar 6 dibawah ini.

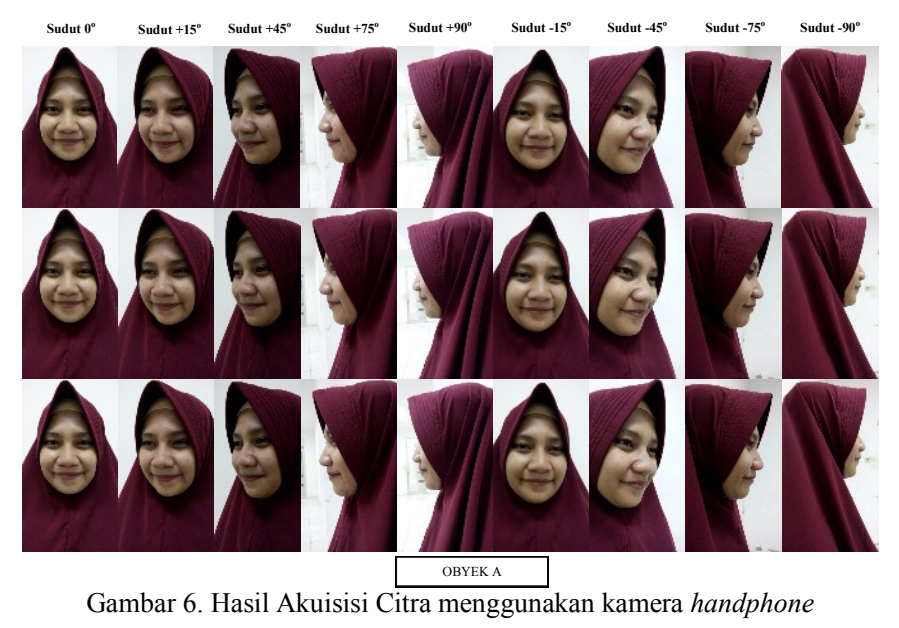

\section{B. Pre-processing}

Gambar 6. Hasil Akuisisi Citra menggunakan kamera handphone

Tahapan pre-processing terbagi menjadi 3 (tiga) proses

yaitu resize image, konversi citra RGB ke grayscale, dan konversi tipe data uint8 ke double. Beberapa tahap yang diakukan adalah sebagai berikut:

- Resize adalah mengubah besarnya ukuran citra digital dalam pixels. Tujuan proses resize pada penelitian ini agar semua citra awal berukuran sama dan untuk mengubah ukuran pixels citra. Semua hasil data citra awal memiliki ukuran 1840 x 3264 pixels. Kemudian di resize menjadi ukuran 230 x 408 pixels. hasil yang diperoleh adalah sebagai berikut:

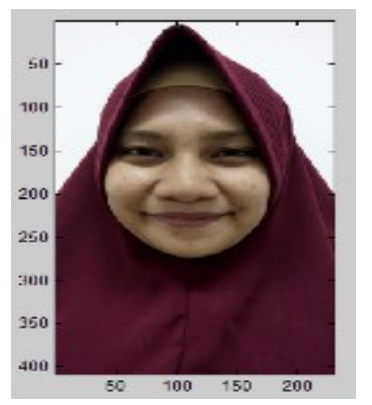

Gambar 7. Citra setelah di resize

Setelah dilakukan proses resize image maka proses selanjutnya yang dilakukan adalah konversi citra warna RGB menjadi citra grayscale untuk mengurangi kompleksitas citra. Default citra yang berjenis 
truecolor RGB (Red, Green, Blue) dikonversi menjadi citra grayscale yang memiliki warna dari warna hitam, keabuan dan putih. Cara mendapatkan citra grayscale adalah dengan mengambil rata-rata nilai RGB. Untuk mengubah citra berwarna menjadi keabuan, syntax "rgb2gray" pada pemrograman MATLAB merupakan fungsi mengubah citra RGB menjadi abu-abu. Berikut adalah hasil dari konversi citra RGB menjadi citra grayscale. Proses konversi citra RGB ke grayscale ditunjukkan pada gambar 10 dibawah ini.

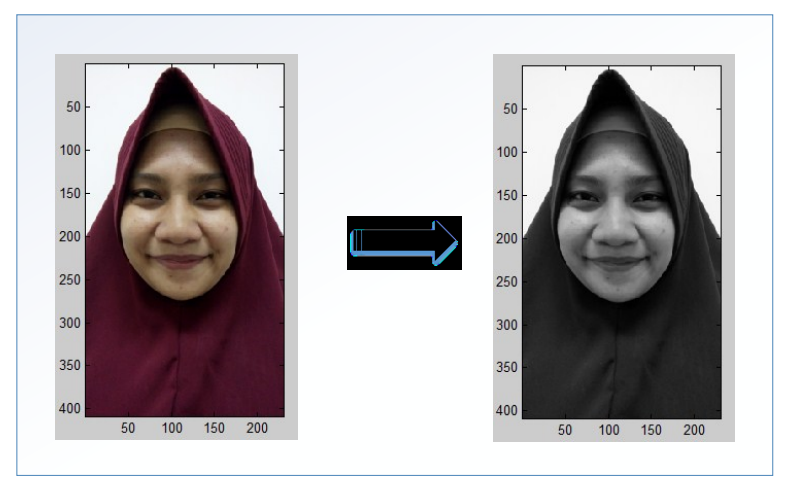

Gambar 8. Convert RGB to Grayscale

Tipe data citra yang tersimpan di dalam matrik di MATLAB pertama kali adalah tipe uint8. Pada aritmatika pada matrik tidak akan bisa dikalkulasi jika tidak memiliki tipe kelas yang sudah ditentukan oleh MATLAB, sehingga citra tersebut harus diubah menjadi tipe data double terlebih dahulu.

\section{Ekstraksi Ciri}

Pada proses ekstraksi ciri menggunakan Correlation Coefficient semua hasil akuisisi obyek wajah telah melalui tahapan pre-processing. Hasil yang ditunjukkan pada proses diatas adalah matriks berukuran $230 \times 230$ yang ditunjukkan pada gambar 9 berikut.

\begin{tabular}{|c|c|c|c|c|c|c|c|c|}
\hline 1 & 0.9956 & 0.9890 & $\ldots \ldots$ & $\ldots \ldots$ & $\ldots \ldots$ & 0.9830 & 0.9897 & 0.9967 \\
\hline 0.9956 & 1 & 0.9959 & $\ldots$. & $\ldots$. & $\ldots$. & 0.9908 & 0.9964 & 0.9944 \\
\hline 0.9890 & 0.9959 & 1 & $\ldots \ldots$ & $\ldots \ldots$ & $\ldots \ldots$ & 0.9969 & 0.9942 & 0.9883 \\
\hline$\ldots \ldots$ & $\ldots \ldots$ & $\ldots \ldots$ & $\ldots \ldots$ & $\ldots \ldots$ & $\ldots \ldots$ & $\ldots \ldots$ & $\ldots \ldots$ & $\ldots \ldots$ \\
\hline$\ldots \ldots$ & $\ldots \ldots$ & $\ldots \ldots$ & $\ldots \ldots$ & $\ldots \ldots$ & $\ldots \ldots$ & $\ldots \ldots$ & $\ldots \ldots$ & $\ldots \ldots$ \\
\hline$\ldots \ldots$ & $\ldots \ldots$ & $\ldots \ldots$ & $\ldots \ldots$ & $\ldots \ldots$ & $\ldots \ldots$ & $\ldots \ldots$ & $\ldots \ldots$ & $\ldots \ldots$ \\
\hline 0.9830 & 0.9908 & 0.9969 & $\ldots \ldots$ & $\ldots \ldots$ & $\ldots \ldots$ & 1 & 0.9948 & 0.9870 \\
\hline 0.9897 & 0.9964 & 0.9942 & $\ldots \ldots$ & $\ldots \ldots$ & $\ldots \ldots$ & 0.9948 & 1 & 0.9943 \\
\hline 0.9967 & 0.9944 & 0.9883 & $\ldots \ldots$ & $\ldots \ldots$ & $\ldots \ldots$ & 0.9870 & 0.9943 & 1 \\
\hline
\end{tabular}

Gambar 9. Hasil Correlation Coefficient

Untuk memudahkan proses komputasi, pada penelitian ini akan dihitung rata-rata baris dan rata-rata kolom dari setiap matriks yang dihasilkan berukuran 1 x 230 yang ditunjukkan pada gambar 10 berikut.

\begin{tabular}{|l|l|l|l|l|l|l|l|l|}
\hline 0.6052 & 0.6055 & 0.6052 & $\ldots$. & $\ldots$. & $\ldots .$. & 0.6029 & 0.6021 & 0.6021 \\
\hline
\end{tabular}

Gambar 10. Rata-Rata Baris dan Kolom Correlation Coefficient

Karena hasil dari rata-rata baris dan kolom masih memiliki banyak nilai, maka proses selanjutnya adalah mencari rata-rata dari hasil rata-rata baris dan kolom sehingga diperoleh satu nilai ciri menggunakan Correlation Coefficient yaitu 0.4865 .

Proses yang telah dijelaskan diatas, digunakan pada semua data citra hasil akuisisi untuk menentukan ciri pada citra pada setiap sudut akuisisi wajah, Setelah melakukan proses MATLAB diatas, maka didapatkan nilai ciri dari 27 citra pada obyek A, B, dan C yang dapat dilihat pada tabel 2, 3, dan 4 .

\begin{tabular}{|l|l|l|l|l|l|}
\hline $\mathbf{A 1}$ & Nilai Ciri & $\mathbf{A 2}$ & Nilai Ciri & $\mathbf{A 3}$ & Nilai Ciri \\
\hline $186 \circ \mathrm{S}$ & 0.4865 & $186^{\circ} \mathrm{S}$ & 0.4871 & $186 \circ \mathrm{S}$ & 0.4859 \\
\hline $163.5 \circ \mathrm{S}$ & $0 . .4599$ & $163.5 \circ \mathrm{S}$ & 0.4591 & $163.5 \circ \mathrm{S}$ & 0.4599 \\
\hline $140.5 \circ \mathrm{SE}$ & 0.4468 & $140.5 \circ \mathrm{SE}$ & 0.4494 & $140.5 \circ \mathrm{SE}$ & 0.4481 \\
\hline $104 \circ \mathrm{SE}$ & 0.3540 & $104 \circ \mathrm{SE}$ & 0.3551 & $104 \circ \mathrm{SE}$ & 0.3562 \\
\hline $76.5 \circ \mathrm{E}$ & 0.3526 & $76.5 \circ \mathrm{E}$ & 0.3540 & $76.5 \circ \mathrm{E}$ & 0.3526 \\
\hline $207 \circ \mathrm{SW}$ & 0.5079 & $207 \circ \mathrm{SW}$ & 0.5110 & $207 \circ \mathrm{SW}$ & 0.5120 \\
\hline $233 \circ \mathrm{SW}$ & 0.3920 & $233 \circ \mathrm{SW}$ & 0.3925 & $233 \circ \mathrm{SW}$ & 0.3910 \\
\hline
\end{tabular}

Optimasi Hasil Akuisisi Wajah Dengan Variasi Proyeksi Menggunakan Kedekatan Pola Jarak Pixel (Arief Bramanto Wicaksono Putra) 


\begin{tabular}{|l|l|l|l|l|l|}
\hline $\mathbf{A 1}$ & Nilai Ciri & A2 & Nilai Ciri & A3 & Nilai Ciri \\
\hline $256.5 \circ \mathrm{W}$ & 0.3095 & $256.5 \circ \mathrm{W}$ & 0.3040 & $256.5 \circ \mathrm{W}$ & 0.2996 \\
\hline $270 \circ \mathrm{W}$ & 0.3940 & $270 \circ \mathrm{W}$ & 0.3961 & $270 \circ \mathrm{W}$ & 0.3964 \\
\hline
\end{tabular}

Table 3. Kumpulan Ciri Obyek B
\begin{tabular}{|l|l|l|l|l|l|}
\hline B1 & Nilai Ciri & B2 & Nilai Ciri & B3 & Nilai Ciri \\
\hline $186^{\circ} \mathrm{S}$ & 0.4406 & $186^{\circ} \mathrm{S}$ & 0.4439 & $186^{\circ} \mathrm{S}$ & 0.4443 \\
\hline $163.5^{\circ} \mathrm{S}$ & 0.4729 & $163.5^{\circ} \mathrm{S}$ & 0.4730 & $163.5^{\circ} \mathrm{S}$ & 0.4768 \\
\hline $140.5^{\circ} \mathrm{SE}$ & 0.3550 & $140.5^{\circ} \mathrm{SE}$ & 0.3562 & $140.5^{\circ} \mathrm{SE}$ & 0.3584 \\
\hline $104 \circ \mathrm{SE}$ & 0.4584 & $104 \circ \mathrm{SE}$ & 0.4622 & $104 \circ \mathrm{SE}$ & 0.4639 \\
\hline $76.5^{\circ} \mathrm{E}$ & 0.3366 & $76.5^{\circ} \mathrm{E}$ & 0.3332 & $76.5^{\circ} \mathrm{E}$ & 0.3328 \\
\hline $207^{\circ} \mathrm{SW}$ & 0.4616 & $207 \circ \mathrm{SW}$ & 0.4600 & $207 \circ \mathrm{SW}$ & 0.4634 \\
\hline $233^{\circ} \mathrm{SW}$ & 0.4875 & $233^{\circ} \mathrm{SW}$ & 0.4862 & $233^{\circ} \mathrm{SW}$ & 0.4869 \\
\hline $256.5^{\circ} \mathrm{W}$ & 0.4035 & $256.5^{\circ} \mathrm{W}$ & 0.4057 & $256.5^{\circ} \mathrm{W}$ & 0.4074 \\
\hline $270^{\circ} \mathrm{W}$ & 0.2140 & $270^{\circ} \mathrm{W}$ & 0.2149 & $270^{\circ} \mathrm{W}$ & 0.2192 \\
\hline
\end{tabular}

Table 4. Kumpulan Ciri Obyek C
\begin{tabular}{|l|l|l|l|l|l|}
\hline C1 & Nilai Ciri & C2 & Nilai Ciri & C3 & Nilai Ciri \\
\hline $186 \circ \mathrm{S}$ & 0.1395 & $186 \circ \mathrm{S}$ & 0.1406 & $186 \circ \mathrm{S}$ & 0.1431 \\
\hline $163.5 \circ \mathrm{S}$ & 0.1528 & $163.5 \circ \mathrm{S}$ & 0.1515 & $163.5 \circ \mathrm{S}$ & 0.1514 \\
\hline $140.5 \circ \mathrm{SE}$ & 0.1053 & $140.5 \circ \mathrm{SE}$ & 0.1029 & $140.5 \circ \mathrm{SE}$ & 0.0996 \\
\hline $104 \circ \mathrm{SE}$ & 0.1241 & $104 \circ \mathrm{SE}$ & 0.1240 & $104 \circ \mathrm{SE}$ & 0.1205 \\
\hline $76.5 \circ \mathrm{E}$ & 0.1043 & $76.5 \circ \mathrm{E}$ & 0.1047 & $76.5 \circ \mathrm{E}$ & 0.1052 \\
\hline $207 \circ \mathrm{SW}$ & 0.1311 & $207 \circ \mathrm{SW}$ & 0.1287 & $207 \circ \mathrm{SW}$ & 0.1301 \\
\hline $233 \circ \mathrm{SW}$ & 0.1692 & $233 \circ \mathrm{SW}$ & 0.1696 & $233 \circ \mathrm{SW}$ & 0.1696 \\
\hline $256.5 \circ \mathrm{W}$ & 0.1434 & $256.5 \circ \mathrm{W}$ & 0.1420 & $256.5 \circ \mathrm{W}$ & 0.1398 \\
\hline $270 \circ \mathrm{W}$ & 0.1051 & $270 \circ \mathrm{W}$ & 0.1049 & $270 \circ \mathrm{W}$ & 0.1049 \\
\hline
\end{tabular}

Keterangan:

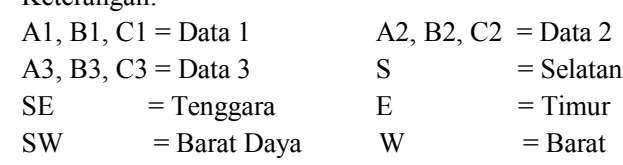

Dari setiap tabel diatas, ada 27 citra hasil akuisisi berdasarkan sudut dan didapatkan nilai ciri Correlation Coefficient yang telah dicari rata-ratanya dari hasil rata-rata baris dan kolom. Citra itu sendiri mempunyai 27 ciri karena setiap data yang diambil 3 kali pengambilan setiap sudut, maka mendapatkan nilai 3 nilai ciri dari setiap sudut. Pada penelitian ini nilai ciri yang diperoleh untuk identitas dari setiap proyeksi.

\section{Pengukuran Jarak Hasil Akuisisi}

Setelah mendapatkan kumpulan ciri untuk setiap data image yang mewakili sudut-sudutnya, dilakukan analisis pengukuran jarak hasil akuisisi dengan menggunakan syntax "dist" yang merupakan fungsi Euclidean Distance pada tools MATLAB dengan contoh syntax pada command window yaitu "Tlu0 = 0.4865 " menunjukkan input nilai ciri sudut $0^{\circ}$ dan "Ka15 $=0.4599$ " adalah input nilai ciri pada sudut $+15^{\circ}$. Kemudian fungsi syntax pada pemrograman MATLAB "dist(Tlu0,Ka15')" untuk mendapatkan nilai jarak antar sudut $0^{\circ}$ dengan sudut $+15^{\circ}$ pada busur yang digunakan. Dan hasil keluaran dari perhitungan jarak itu adalah 0.0266 pada kolom A1 yang pertama.

Jarak antar sudut itu untuk mengetahui jarak hasil akuisisinya semakin mendekat atau menjauh. Kemudian ulangi program diatas untuk menentukan jarak dari berbagai sudut akuisisinya. Data dari jarak setiap sudut pengambilan akuisisi pada obyek A, B, dan C ditunjukkan pada tabel 5, 6, dan 7 .

Table 5. Jarak Antar Sudut Akuisisi Obyek A

\begin{tabular}{|l|l|l|l|}
\hline Jarak antar sudut & $\mathbf{A 1}$ & $\mathbf{A 2}$ & $\mathbf{A 3}$ \\
\hline $186 \circ \mathrm{S}-163.5^{\circ} \mathrm{S}$ & 0.0266 & 0.0280 & 0.0260 \\
\hline $186 \circ \mathrm{S}-140.5 \circ \mathrm{SE}$ & 0.0397 & 0.0377 & 0.0378 \\
\hline $186 \circ \mathrm{S}-256.5 \circ \mathrm{W}$ & 0.1770 & 0.1831 & 0.1893 \\
\hline $186 \circ \mathrm{S}-270 \circ \mathrm{W}$ & 0.0925 & 0.0910 & 0.0895 \\
\hline $163.5 \circ \mathrm{S}-140.5 \circ \mathrm{SE}$ & 0.0131 & 0.0097 & 0.0118 \\
\hline $163.5 \circ \mathrm{S}-256.5^{\circ} \mathrm{W}$ & 0.1504 & 0.1551 & 0.1633 \\
\hline $163.5^{\circ} \mathrm{S}-270 \circ \mathrm{W}$ & 0.0659 & 0.0630 & 0.0635 \\
\hline
\end{tabular}

Optimasi Hasil Akuisisi Wajah Dengan Variasi Proyeksi Menggunakan Kedekatan Pola Jarak Pixel (Arief Bramanto Wicaksono Putra) 


\begin{tabular}{|l|l|l|l|}
\hline Jarak antar sudut & A1 & A2 & $\mathbf{A 3}$ \\
\hline $140.5 \circ \mathrm{SE}-104 \circ \mathrm{SE}$ & 0.0928 & 0.0943 & 0.0919 \\
\hline $104 \circ \mathrm{SE}-76.5^{\circ} \mathrm{E}$ & 0.0014 & 0.0011 & 0.0036 \\
\hline $104 \circ \mathrm{SE}-270^{\circ} \mathrm{W}$ & 0.0400 & 0.0410 & 0.0402 \\
\hline
\end{tabular}

Table 6. Jarak Antar Sudut Akuisisi Obyek B

\begin{tabular}{|l|l|l|l|}
\hline Jarak antar sudut & B1 & B2 & B3 \\
\hline $186^{\circ} \mathrm{S}-163.5 \circ \mathrm{S}$ & 0.0323 & 0.0291 & 0.0325 \\
\hline $186 \circ \mathrm{S}-23 \circ^{\circ} \mathrm{SW}$ & 0.0469 & 0.0423 & 0.0426 \\
\hline $186 \circ \mathrm{S}-256.5 \circ \mathrm{W}$ & 0.0371 & 0.0382 & 0.0369 \\
\hline $186 \circ \mathrm{S}-270 \circ \mathrm{W}$ & 0.2266 & 0.2290 & 0.2251 \\
\hline $163.5 \circ \mathrm{S}-140.5 \circ \mathrm{SE}$ & 0.1179 & 0.1168 & 0.1184 \\
\hline $163.5 \circ \mathrm{S}-256.5 \circ \mathrm{W}$ & 0.0694 & 0.0673 & 0.0694 \\
\hline $163.5 \circ \mathrm{S}-270 \circ \mathrm{W}$ & 0.2589 & 0.2581 & 0.2576 \\
\hline $140.5 \circ \mathrm{SE}-104 \circ \mathrm{SE}$ & 0.1034 & 0.1060 & 0.1055 \\
\hline $104 \circ \mathrm{SE}-76.5 \circ \mathrm{E}$ & 0.1218 & 0.1290 & 0.1311 \\
\hline $104 \circ \mathrm{SE}-270^{\circ} \mathrm{W}$ & 0.2444 & 0.2473 & 0.2447 \\
\hline
\end{tabular}

Table 7. Jarak Antar Sudut Akuisisi Obyek C

\begin{tabular}{|l|l|l|l|}
\hline Jarak antar sudut & C1 & C2 & C3 \\
\hline $186^{\circ} \mathrm{S}-163.5 \circ \mathrm{S}$ & 0.0133 & 0.0109 & 0.0083 \\
\hline $186^{\circ} \mathrm{S}-140.5 \circ \mathrm{SE}$ & 0.0342 & 0.0377 & 0.0435 \\
\hline $186^{\circ} \mathrm{S}-233^{\circ} \mathrm{SW}$ & 0.0297 & 0.0290 & 0.0265 \\
\hline $186 \circ \mathrm{S}-256.5 \circ \mathrm{W}$ & 0.0039 & 0.0014 & 0.0033 \\
\hline $186^{\circ} \mathrm{S}-27 \circ^{\circ} \mathrm{W}$ & 0.0344 & 0.0357 & 0.0382 \\
\hline $163.5 \circ \mathrm{S}-256.5 \circ \mathrm{W}$ & 0.0094 & 0.0095 & 0.0116 \\
\hline $163.5 \circ \mathrm{S}-270 \circ \mathrm{W}$ & 0.0477 & 0.0466 & 0.0465 \\
\hline $140.5 \circ \mathrm{SE}-104 \circ \mathrm{SE}$ & 0.0188 & 0.0211 & 0.0209 \\
\hline $104 \circ \mathrm{SE}-76.5 \circ \mathrm{E}$ & 0.0198 & 0.0193 & 0.0153 \\
\hline $104 \circ \mathrm{SE}-270^{\circ} \mathrm{W}$ & 0.0190 & 0.0191 & 0.0156 \\
\hline
\end{tabular}

Dari tabel 5, 6, dan 7 diatas dari setiap sudut pengambilan obyek A, obyek B, dan obyek C dicari jarak antar sudutnya dengan menggunakan Euclidean Distance pada fungsi MATLAB untuk mendapatkan pengukuran jarak antar sudutnya.

\section{E. Pengujian}

Dari data tabel pengukuran jarak antar sudut dilakukan uji performansi dimana selisih antar jarak yang diperoleh akan menjadi nilai performansi akuisisi. Diketahui tabel 8 data nomor 1 bagian a pada kolom A1 dengan nilai 0.0266 , A2 dengan nilai 0.0280 , dan A3 dengan nilai 0.0260 dilakukan proses perhitungan mean atau rata-rata sebagai berikut :

$$
\bar{x}=\frac{1}{3}(0.0266+0.0280+0.0260)
$$

Dari perhitungan diatas menghasilkan nilai mean 0.0269. Proses perhitungan mean berlaku pula pada data tabel selanjutnya. Kemudian untuk mendapatkan nilai performansi pada proyeksi nomor 1 adalah dengan menghitung selisih antara data mean $1 \mathrm{a}$ dan $1 \mathrm{~b}$ yaitu 0.0269 dikurang 0.0238 maka hasil performansinya 0.0031 . Pada penelitian ini nilai selisih dicari dengan fungsi "ABS" pada Microsoft Excel. Data tabel hasil perbandingan variasi sudut dari obyek A, B, dan $\mathrm{C}$ ditunjukkan pada tabel 8, 9, dan 10.

Table 8. Hasil Perbandingan Variasi Sudut Obyek A

\begin{tabular}{|l|l|l|l|l|l|l|l|}
\hline \multicolumn{2}{|l|}{ No } & Perbandingan Proyeksi & A1 & A2 & A3 & Mean & Hasil \\
\hline \multirow{2}{*}{1} & a & $186^{\circ} \mathrm{S}-163.5^{\circ} \mathrm{S}$ & 0.0266 & 0.0280 & 0.0260 & 0.0269 & \multirow{2}{*}{0.0031} \\
\cline { 2 - 8 } & $\mathrm{b}$ & $186^{\circ} \mathrm{S}-207 \circ \mathrm{SW}$ & 0.0214 & 0.0239 & 0.0261 & 0.0238 & \\
\hline \multirow{2}{*}{2} & $\mathrm{a}$ & $186^{\circ} \mathrm{S}-140.5^{\circ} \mathrm{SE}$ & 0.0397 & 0.0377 & 0.0378 & 0.0384 & \multirow{2}{*}{0.0563} \\
\cline { 2 - 7 } & $\mathrm{b}$ & $186^{\circ} \mathrm{S}-233^{\circ} \mathrm{SW}$ & 0.0945 & 0.0946 & 0.0949 & 0.0947 & \\
\hline
\end{tabular}

Optimasi Hasil Akuisisi Wajah Dengan Variasi Proyeksi Menggunakan Kedekatan Pola Jarak Pixel (Arief Bramanto Wicaksono Putra) 


\begin{tabular}{|c|c|c|c|c|c|c|c|}
\hline \multicolumn{2}{|c|}{ No } & Perbandingan Proyeksi & A1 & A2 & A3 & Mean & Hasil \\
\hline \multirow{2}{*}{3} & $\mathrm{a}$ & $186^{\circ} \mathrm{S}-104 \circ \mathrm{SE}$ & 0.1325 & 0.1320 & 0.1297 & 0.1314 & \multirow{2}{*}{0.0517} \\
\hline & $\mathrm{b}$ & $186^{\circ} \mathrm{S}-256.5^{\circ} \mathrm{W}$ & 0.1770 & 0.1831 & 0.1893 & 0.1831 & \\
\hline \multirow{2}{*}{4} & $\mathrm{a}$ & $186^{\circ} \mathrm{S}-76.5^{\circ} \mathrm{E}$ & 0.1339 & 0.1331 & 0.1333 & 0.1334 & \multirow{2}{*}{0.0424} \\
\hline & $\mathrm{b}$ & $186^{\circ} \mathrm{S}-270^{\circ} \mathrm{W}$ & 0.0925 & 0.0910 & 0.0895 & 0.0910 & \\
\hline \multirow{4}{*}{5} & $\mathrm{a}$ & $163.5 \circ \mathrm{S}-140.5 \circ \mathrm{SE}$ & 0.0131 & 0.0097 & 0.0118 & 0.0115 & \multirow{4}{*}{0.0563} \\
\hline & $\mathrm{b}$ & $163.5 \circ \mathrm{S}-233 \circ \mathrm{SW}$ & 0.0679 & 0.0666 & 0.0689 & 0.0678 & \\
\hline & $\mathrm{b}$ & $140.5^{\circ} \mathrm{SE}-256.5^{\circ} \mathrm{W}$ & 0.1373 & 0.1464 & 0.1515 & 0.1447 & \\
\hline & $\mathrm{b}$ & $104 \circ \mathrm{SE}-270 \circ \mathrm{W}$ & 0.0400 & 0.0410 & 0.0402 & 0.0404 & \\
\hline
\end{tabular}

Table 9. Hasil Perbandingan Variasi Sudut Obyek B

\begin{tabular}{|c|c|c|c|c|c|c|c|}
\hline \multicolumn{2}{|c|}{ No } & Perbandingan Proyeksi & B1 & B2 & B3 & Mean & Hasil \\
\hline \multirow{2}{*}{1} & $\mathrm{a}$ & $186^{\circ} \mathrm{S}-163.5^{\circ} \mathrm{S}$ & 0.0323 & 0.0291 & 0.0325 & 0.0313 & \multirow{2}{*}{0.0126} \\
\hline & $\mathrm{b}$ & $186^{\circ} \mathrm{S}-207 \circ \mathrm{SW}$ & 0.0210 & 0.0161 & 0.0191 & 0.0187 & \\
\hline \multirow{2}{*}{2} & $\mathrm{a}$ & $186^{\circ} \mathrm{S}-140.5^{\circ} \mathrm{SE}$ & 0.0856 & 0.0877 & 0.0859 & 0.0864 & \multirow{2}{*}{0.0425} \\
\hline & $\mathrm{b}$ & $186^{\circ} \mathrm{S}-233^{\circ} \mathrm{SW}$ & 0.0469 & 0.0423 & 0.0426 & 0.0439 & \\
\hline \multirow{2}{*}{3} & $\mathrm{a}$ & $186^{\circ} \mathrm{S}-104 \circ \mathrm{SE}$ & 0.0178 & 0.0183 & 0.0196 & 0.0186 & \multirow{2}{*}{0.0188} \\
\hline & $\mathrm{b}$ & $186^{\circ} \mathrm{S}-256.5^{\circ} \mathrm{W}$ & 0.0371 & 0.0382 & 0.0369 & 0.0374 & \\
\hline \multirow{2}{*}{4} & $\mathrm{a}$ & $186^{\circ} \mathrm{S}-76.5^{\circ} \mathrm{E}$ & 0.1040 & 0.1107 & 0.1115 & 0.1087 & \multirow{2}{*}{0.1182} \\
\hline & $\mathrm{b}$ & $186^{\circ} \mathrm{S}-270 \circ \mathrm{W}$ & 0.2266 & 0.2290 & 0.2251 & 0.2269 & \\
\hline \multirow{2}{*}{5} & $\mathrm{a}$ & $163.5 \circ \mathrm{S}-140.5 \circ \mathrm{SE}$ & 0.1179 & 0.1168 & 0.1184 & 0.1177 & \multirow{2}{*}{0.1051} \\
\hline & $\mathrm{b}$ & $163.5 \circ \mathrm{S}-233 \circ \mathrm{SW}$ & 0.0146 & 0.0132 & 0.0101 & 0.0126 & \\
\hline
\end{tabular}

Table 10. Hasil Perbandingan Variasi Sudut Obyek C

\begin{tabular}{|c|c|c|c|c|c|c|c|}
\hline \multicolumn{2}{|c|}{ No } & Perbandingan Proyeksi & $\mathrm{C1}$ & $\mathrm{C2}$ & C3 & Mean & Hasil \\
\hline \multirow{2}{*}{1} & $\mathrm{a}$ & $186 \circ \mathrm{S}-163.5 \circ \mathrm{S}$ & 0.0133 & 0.0109 & 0.0083 & 0.0108 & \multirow{2}{*}{0.0003} \\
\hline & $\mathrm{b}$ & $186^{\circ} \mathrm{S}-207 \circ \mathrm{SW}$ & 0.0084 & 0.0119 & 0.0130 & 0.0111 & \\
\hline \multirow{2}{*}{2} & $\mathrm{a}$ & $186^{\circ} \mathrm{S}-140.5^{\circ} \mathrm{SE}$ & 0.0342 & 0.0377 & 0.0435 & 0.0385 & \multirow{2}{*}{0.0101} \\
\hline & $\mathrm{b}$ & $186^{\circ} \mathrm{S}-233^{\circ} \mathrm{SW}$ & 0.0297 & 0.0290 & 0.0265 & 0.0284 & \\
\hline \multirow{2}{*}{3} & $\mathrm{a}$ & $186^{\circ} \mathrm{S}-104^{\circ} \mathrm{SE}$ & 0.0154 & 0.0166 & 0.0226 & 0.0182 & \multirow{2}{*}{0.0153} \\
\hline & $\mathrm{b}$ & $186^{\circ} \mathrm{S}-256.5^{\circ} \mathrm{W}$ & 0.0039 & 0.0014 & 0.0033 & 0.0029 & \\
\hline \multirow{2}{*}{4} & $\mathrm{a}$ & $186^{\circ} \mathrm{S}-76.5^{\circ} \mathrm{E}$ & 0.0352 & 0.0359 & 0.0379 & 0.0363 & \multirow{2}{*}{0.0002} \\
\hline & $\mathrm{b}$ & $186^{\circ} \mathrm{S}-270^{\circ} \mathrm{W}$ & 0.0344 & 0.0357 & 0.0382 & 0.0361 & \\
\hline \multirow{3}{*}{5} & $\mathrm{a}$ & $163.5 \circ \mathrm{S}-140.5 \circ \mathrm{SE}$ & 0.0475 & 0.0486 & 0.0518 & 0.0493 & \multirow{3}{*}{0.0317} \\
\hline & $\mathrm{b}$ & $163.5^{\circ} \mathrm{S}-233^{\circ} \mathrm{SW}$ & 0.0164 & 0.0181 & 0.0182 & 0.0176 & \\
\hline & $\mathrm{b}$ & $104 \circ \mathrm{SE}-270 \circ \mathrm{W}$ & 0.0190 & 0.0191 & 0.0156 & 0.0179 & \\
\hline
\end{tabular}

Pada tabel 8, 9, dan 10 diketahui bahwa hasil uji perbandingan jarak antara sudut ke arah kanan dan kiri yang dirata-ratakan lalu dihitung lagi selisih jaraknya mendapatkan hasil nilai performansi akuisisi.

Tabel 11. Hasil Perbandingan Obyek A, B, C

\begin{tabular}{|c|c|c|c|c|}
\hline & \multirow{2}{*}{ Perbandingan Proyeksi } & \multicolumn{3}{|c|}{ Hasil Performansi } \\
\hline & & Obyek A & Obyek B & Obyek C \\
\hline \multirow{2}{*}{1} & $186^{\circ} \mathrm{S}-163.5^{\circ} \mathrm{S}$ & \multirow{2}{*}{0.0031} & \multirow{2}{*}{0.0126} & \multirow{2}{*}{0.0003} \\
\hline & $186^{\circ} \mathrm{S}-207 \circ \mathrm{SW}$ & & & \\
\hline \multirow{2}{*}{2} & $186^{\circ} \mathrm{S}-140.5^{\circ} \mathrm{SE}$ & \multirow{2}{*}{0.0563} & \multirow{2}{*}{0.0425} & \multirow{2}{*}{0.0101} \\
\hline & $186^{\circ} \mathrm{S}-233^{\circ} \mathrm{SW}$ & & & \\
\hline \multirow{2}{*}{3} & $186^{\circ} \mathrm{S}-104 \circ \mathrm{SE}$ & \multirow{2}{*}{0.0517} & \multirow{2}{*}{0.0188} & \multirow{2}{*}{0.0153} \\
\hline & $186^{\circ} \mathrm{S}-256.5^{\circ} \mathrm{W}$ & & & \\
\hline \multirow{2}{*}{4} & $186^{\circ} \mathrm{S}-76.5^{\circ} \mathrm{E}$ & \multirow{2}{*}{0.0424} & \multirow{2}{*}{0.1182} & \multirow{2}{*}{0.0002} \\
\hline & $186^{\circ} \mathrm{S}-270 \circ \mathrm{W}$ & & & \\
\hline \multirow{3}{*}{5} & $163.5 \circ \mathrm{S}-140.5 \circ \mathrm{SE}$ & \multirow{3}{*}{0.0563} & \multirow{3}{*}{0.1051} & \multirow{3}{*}{0.0317} \\
\hline & $163.5^{\circ} \mathrm{S}-233^{\circ} \mathrm{SW}$ & & & \\
\hline & $104 \circ \mathrm{SE}-270^{\circ} \mathrm{W}$ & & & \\
\hline
\end{tabular}

Dari tabel 9 yang merupakan hasil performansi dari akuisisi sudut pada obyek A, B, dan C berdasarkan selisih jarak variasi sudut maka semakin kecil nilai performansi yang diperoleh dari selisih jarak tersebut maka hasil akuisisi semakin bagus dan resiko kesalahan akuisisi yang dilakukan semakin sedikit. 


\section{PENUTUP}

Dari penelitian yang telah dilakukan dapat diambil kesimpulan sebagai berikut :

- Pada penelitian ini telah dilakukan akuisisi pada obyek wajah dengan ukuran citra 1840 x 3264 piksel dengan 9 sampel sudut

- Untuk pengujian hasil akuisisi citra dengan variasi sudut dilakukan ekstraksi ciri menggunakan metode Correlation Coefficient dan Euclidean Distance untuk mendapatkan nilai hasil perfomansi akuisisi berdasarkan variasi sudut. Dimana nilai performansi variasi sudut yang diperoleh dengan selisih jarak semakin maka hasil akuisisi dinyatakan lebih optimal

Pada obyek A hasil performansi akuisisi yang terbaik adalah sudut $0^{\circ}$ terhadap $+15^{\circ}$ dan $-15^{\circ}$ dengan nilai performansi 0.0031 dan yang terburuk adalah sudut $0^{\circ}$ terhadap $+45^{\circ}$ dan $-45^{\circ}$ dengan nilai performansi 0.0563 . Pada obyek B hasil performansi akuisisi yang terbaik adalah sudut $0^{\circ}$ terhadap $+15^{\circ}$ dan $-15^{\circ}$ dengan nilai performansi 0.0126 dan yang terburuk adalah sudut $0^{\circ}$ terhadap $+90^{\circ}$ dan $-90^{\circ}$ dengan nilai performansi 0.1182 . Dan pada obyek $C$ hasil performansi akuisisi yang terbaik adalah sudut $0^{\circ}$ terhadap $+90^{\circ}$ dan $-90^{\circ}$ dengan nilai performansi 0.0002 dan yang terburuk adalah sudut $+15^{\circ}$ terhadap $+45^{\circ}$ dan $-45^{\circ}$ dengan nilai performansi 0.0317 .

\section{ACKNOWLEDGMENT}

Terima kasih kepada Laboratorium dan Modern Computimg Research Center Jurusan Teknologi Informasi Politeknik Negeri Samarinda atas kesempatan penulis melakukan penelitian dan support secara teknis dan finansial selama melakukan penelitian.

\section{DAFTAR PUSTAKA}

[1] Sunardi and S. Saifullah, "Thermal Imaging Untuk Identifikasi Telur," in Prosiding Konferensi Nasional Ke-4 Prosiding Konferensi Nasional Ke- 4 Asosiasi Program Pascasarjana Perguruan Tinggi Muhammadiyah (APPPTM), 2016, no. May, p. 157.

[2] A. B. W. Putra and M. H. HP, "Verifikasi Pola Tanda Tangan Dosen IT POLNES Menggunakan Fuzzy Rule Base”, SMARTICS, vol. 1, no. 1, pp. 6-13, Oct. 2015.

[3] A. B. W. Putra, D. S. B. Utomo, and M. D. Rahmawan, "Verifikasi Golongan Darah Manusia Berbasis Citra Dijital Menggunakan Logika Fuzzy,” J. Sains Terap., vol. 4, no. 1, 2018

[4] S. Waluya and A. Wiyono, "Pengaruh Media Pembelajaran Menggunakan Program Sketchup terhadap Kemampuan Menggambar Proyeksi Ortogonal Siswa di SMK Negeri 2 Surabaya,” J. Kaji. Pendidik. Tek. Bangunan, vol. 3, no. 3, pp. 57-74, 2015.

[5] A. T. Susanto, K. Kurnianto, D. Handoyo, and F. Suryaningsih, "Modul Perangkat Lunak Akuisisi Citra Dan Kendali Meja Putar Prototipe Perangkat Radioskopi Untuk Industri Manufaktur," J. PRIMA, vol. 14, no. 1, pp. 10-19, 2017.

[6] R. Syam et al., "Penentuan Nilai Standar Distorsi Berminyak Pada Akuisisi Citra Sidik Jari," J. MAKARA, Teknol., vol. 15, no. 1, pp. 55-62, 2011.

[7] A. B. W. P, S. H. Pramono, and A. Naba, "Rancang Bangun Prototype Ciri Citra Kulit Luar Kayu Tanaman Karet menggunakan Metode Virtual Center Of Gravity,” J. EECCIS, vol. 8, no. 1, pp. 19$26,2014$.

[8] A. B. W. Putra and E. Subkhiana, "Ekstraksi Ciri Entropy Untuk Pengenalan Pola Wajah Menggunakan Fuzzy Rule Base,” J. SMARTICS, vol. 2, no. 2, pp. 35-42, 2016

[9] A. B. W Putra and D. Pandiangan, "Pengenalan Pola Wajah Untuk Simulasi Presensi Mahasiswa", SMARTICS, vol. 2, no. 1, pp. 15-20, Apr. 2016

[10] E. Haryati, R. Widita, and S. Viridi, "Optimasi Sudut Proyeksi pada Rekonstruksi Citra CT," in Prosiding Simposium Nasional Inovasi Pembelajaran dan Sains 2011 (SNIPS 2011), 2011, vol. 2011, no. SNIPS, pp. 22-23.

[11] H. Kurniawan and T. Hidayat, "Perancangan Program Pengenalan Wajah Menggunakan Fungsi Jarak Metode Euclidean Pada Matlab," in Seminar Nasional Aplikasi Teknologi Informasi 2008 (SNATI 2008), 2008, vol. 2008, no. Snati, pp. 15-18.

[12] D. Nugraheny, "Metode Nilai Jarak Guna Kesamaan atau Kemiripan Ciri Suatu Citra (Kasus Deteksi Awan Cumulonimbus Menggunakan Principal Component Analysis)," J. ANGKASA, vol. VII, Nomor, pp. 21-30, 2015. 